\title{
Simple Procedures for the Preparation of D-Ribose-5-phosphate Ketol-Isomerase, D-Ribulose-5-phosphate 3-Epimerase and D-Sedoheptulose-7-phosphate: D-Glyceraldehyde-3-phosphate Glycolaldehydetransferase ${ }^{\dagger}$
}

\author{
Ken-ichi SASAIIMA and Masahiko YonedA \\ Microbiological Research Laboratories, Central Research Division, \\ Takeda Chemical Industries, Ltd., Higashiyodogawa, Osaka, Japan
}

Received December 4, 1973

\begin{abstract}
D-Ribose-5-phophate ketol-isomerase (EC 5.3.1.6), D-ribulose-5-phosphate 3-epimerase (EC 5.1.3.1) and D-sedoheptulose-7-phosphate: D-glyceraldehyde-3-phosphate glycolaldehydetransferase (EC 2.2.1.1) have been partially purified. D-Ribose-5-phosphate ketol-isomerase was purified from spinach by column chromatography with DEAE-cellulose and DEAESephadex A-50; D-ribulose-5-phosphate 3-epimerase was purified from baker's yeast by column chromatography with DEAE-cellulose; and D-sedoheptulose-7-phosphate: D-glyceraldehyde3-phosphate glycolaldehydetransferase was purified from a Bacillus species No. 102 mutant G3-46-22-6 by column chromatography with DEAE-cellulose. The preparations were used for the determination of the activities of these enzymes in the parent and D-ribose-forming mutants of a Bacillus species.
\end{abstract}

Mutants which were thought to be defective in the non-oxidative section of the pentose phosphate pathway were isolated ${ }^{11}$ and $\mathrm{D}$ ribose accumulation by these strains was reported previously. ${ }^{2}$ This work was undertaken to obtain enzymes for the determination of the mutation points of these mutants.

Methods for the determination of enzyme activities in the non-oxidative section of the pentose phosphate pathway have already been described by many investigators. ${ }^{3 \sim 9)}$ Investigations for the determination of these enzyme activities have also been carried out recently. ${ }^{10,11)}$ To determine the activities of the three enzymes of the non-oxidative section, D-ribose-5-phosphate ketol-isomerase (RPI), D-ribulose-5-phosphate 3-epimerase (RPE) and D-sedoheptulose-7-phosphate: D-glyceraldehyde-3-phosphate glycolaldehydetransferase (transketolase) (TK), we adopted spectrophotometrical methods ${ }^{12)}$ in which each enzyme

$\dagger$ Carbohydrate Metabolism Mutants of a Bacillus Species (Part III); presented at the Annual Meeting of the Agricultural Chemical Society of Japan in April, 1970. activity was assayed in terms of NADH oxidation with D-ribose-5-phosphate as the substrate in the presence of sufficient amounts of the other two enzymes, triosephosphate isomerase (EC 5.3.1.1) and $\alpha$-glycerophosphate dehydrogenase (EC 1.1.1.8) (Fig. 1). Although triosephosphate isomerase and $\alpha$-glycerophosphate dehydrogenase could be obtained commercially it was necessary to prepare three enzymes, RPI, RPE and TK preparations. These enzymes have been purified previously from various materials such as yeast, ${ }^{13 \sim 17)}$ Escherichia coli, ${ }^{18,19)}$ Lactobacillus pentosus, ${ }^{181}$ Aerobacter aerogenes, ${ }^{20)}$ calf spleen, ${ }^{21)}$ rat liver, ${ }^{10,22)}$ human erythrocyte, ${ }^{23)}$ spinach $^{6,22,24)}$ and alfalfa. $^{3}$ In this study, we attempted to prepare the enzymes as simply as possible from convenient sources available in our laboratories, with special reference to the separation of the enzymes from each other rather than the degree of their purity. Column chromatography with ion-exchange Sephadex has been used in the purification of the three enzymes. ${ }^{17,18,20,24}$ However, there has been no attempt to separate the three enzymes systematically by column 


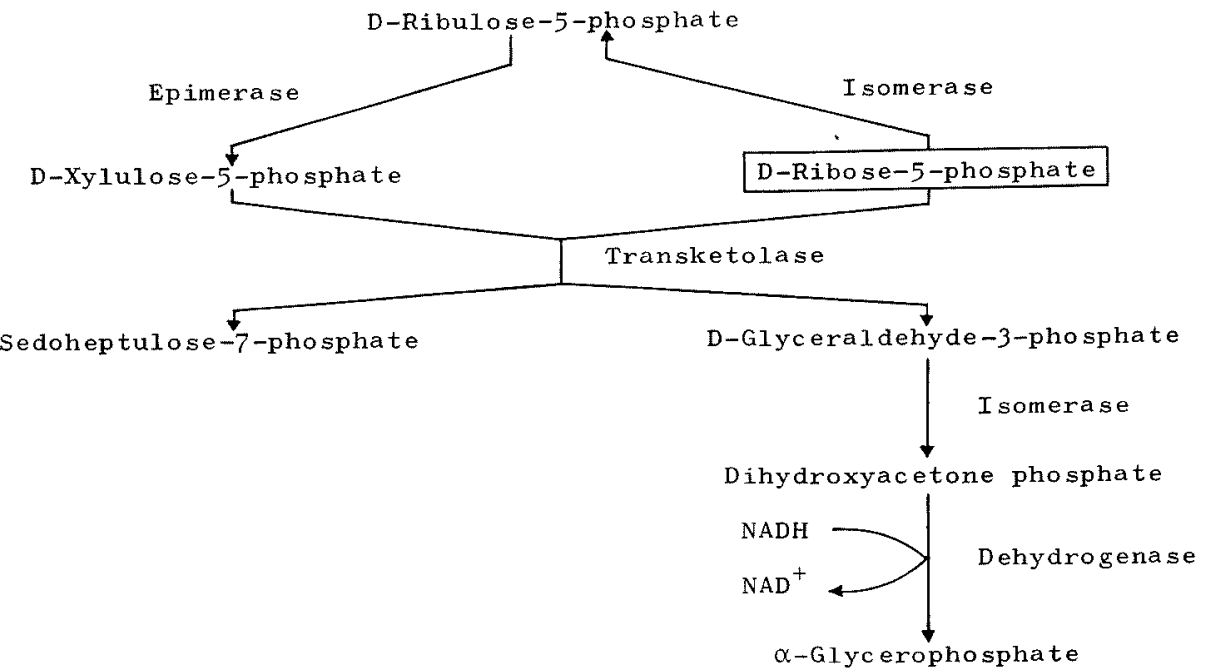

Frg. 1. Scheme for the Determination of Enzyme Activities of the Non-oxidative Section of the Pentose Phosphate Pathway.

chromatography with ion-exchange cellulose or ion-exchange Sephadex. We studied the separation of the enzymes of a Bacillus species, spinach and baker's yeast by DEAE-cellulose or DEAE-Sephadex column chromatography and succeeded in obtaining enzyme preparations suitable for the determination of the enzyme activities.

This paper deals with the preparation of these enzymes and the method of determination of each enzyme activity.

\section{MATERIALS AND METHODS}

Enzyme sources. Spinach, baker's yeast and a Bacillus species No. 102 mutant G3-46-22-6 (the parent of D-ribose-forming strains) were used as enzyme sources for RPI, RPE and TK preparations, respectively. Baker's yeast was purchased from Oriental Yeast Ind. Co., Ltd.

\section{Preparation of cell extracts}

a) Spinach. Fifty grams of leaves were treated in a Universal Homogenizer (Nihonseiki Seisakusho) with the same weight of $0.01 \mathrm{M}$ Tris- $\mathrm{HCl}$ buffer ( $\mathrm{pH} 7.5$ ) containing $0.001 \mathrm{M}$ mercaptoethanol. The homogenate was filtered through cotton gauze. The filtrate was centrifuged at $1.2 \times 10^{4} \mathrm{~g}$ for $20 \mathrm{~min}$. The supernatant was used as the cell extract.

b) Baker's yeast. Baker's yeast was suspended in twice its weight of the same buffer used for spinach. Thirty-milliliter portions of the suspension were treated with an ultrasonic oscillator, Insonator (Kubota Seisakusho) at $160 \mathrm{~W}$ for $20 \mathrm{~min}$. The supernatant was used as the cell extract after cellular debris was removed by centrifugation.

c) A Bacillus species No. 102 mutant G3-46-22-6. A loopful of the slant culture on a complete medium was transferred into $200 \mathrm{ml}$ of a modified Spizizen's medium $^{1 /}$ containing $0.5 \%$ sorbitol and $0.5 \%$ sodium L-glutamate as carbon sources in a one-liter flask and incubated at $37^{\circ} \mathrm{C}$ on a rotary shaker. After $16 \mathrm{hr}$ cultivation, the cells were harvested by centrifugation, washed with $0.01 \mathrm{M}$ Tris- $\mathrm{HCl}$ buffer ( $\mathrm{pH} 7.5$ ) containing $0.001 \mathrm{M}$ mercaptoethanol and resuspended in the same buffer so that the optical density at $650 \mathrm{~nm}$ of the cell suspension was adjusted to 10 . Then, egg white lysozyme was added to the cell suspension at a concentration of $50 \gamma$ per $\mathrm{ml}$. The suspension was incubated at $37^{\circ} \mathrm{C}$ for 30 to $90 \mathrm{~min}$. The cellular debris was removed by centrifugation $\left(1.2 \times 10^{4} \mathrm{~g}\right)$ and the supernatant was used as the cell extract.

\section{Column chromatography}

a) Spinach cell extract. Fifty milliliters of the cell extract ( $870 \mathrm{mg}$ of protein) was applied to a DEAEcellulose column $\left(3.1 \mathrm{~cm}^{2} \times 30 \mathrm{~cm}\right)$ equilibrated with $0.01 \mathrm{M}$ Tris- $\mathrm{HCl}$ buffer ( $\mathrm{pH} 7.5$ ) containing $0.001 \mathrm{M}$ mercaptoethanol. The protein was eluted with the same buffer containing ammonium sulfate in a linear gradient from 0 to $0.2 \mathrm{M}$. The flow rate was $1.0 \mathrm{ml}$ per min. Ten-milliliter portions were collected in test tubes.

Next, the eluate containing RPI and RPE (60 ml, 344 mg of protein) was applied to a DEAE-Sephadex A-50 column $\left(3.1 \mathrm{~cm}^{2} \times 30 \mathrm{~cm}\right)$ previously equilibrated with 
$0.01 \mathrm{~m}$ maleate buffer ( $\mathrm{pH} 6.5$ ). The protein was eluted stepwise with the same buffer containing ammonium sulfate at concentrations of $0.01 \mathrm{M}, 0.05 \mathrm{M}$ and $0.2 \mathrm{M}$ in turn.

b) Baker's yeast cell extract. Fifty milliliters of the cell extract ( $390 \mathrm{mg}$ of protein) was treated in the same manner as in the case of spinach DEAE-cellulose column chromatography.

c) Bacillus species No. 102 mutant G3-46-22-6 cell extract. One-hundred milliliters of the cell extract (350 $\mathrm{mg}$ of protein) was chromatographed in much the same way as in the case of spinach.

Determination of the enzyme activity. RPI, RPE and TK activities were each assayed spectrophotometrically ${ }^{12}$, with D-ribose-5-phosphate as a substrate in the presence of the other two enzymes, triosephosphate isomerase and $\alpha$-glycerophosphate dehydrogenase. The reaction mixture of Srere et al. ${ }^{251}$ was modified as shown below. The rate of oxidation of NADH was measured with a Gilford Multiple Sample Absorbance Recorder 2000 at $30^{\circ} \mathrm{C}$. One unit of enzyme activity was defined as the amount of enzyme which oxidized $1 \mu$ mole of NADH per minute. Specific activity was defined as units per $\mathrm{mg}$ of protein.

a) Determination of RPI activity. The reaction mixtures A and B were as follows; A $(0.9 \mathrm{ml}): 20$ $\mu$ moles of D-ribose-5-phosphate, $20 \mu$ moles of $\mathrm{MgCl}_{2}$, $0.43 \mu$ mole of thiamine pyrophosphate, sufficient RPE and TK, and $60 \mu$ moles of Tris- $\mathrm{HCl}$ buffer ( $\mathrm{pH} 7.5$ ); B $(1.09 \mathrm{ml}): 0.75 \mu$ mole of $\mathrm{NADH}, 0.66$ unit of $a-$ glycerophosphate dehydrogenase containing sufficient triosephosphate isomerase, RPE and TK, and $40 \mu$ moles of Tris- $\mathrm{HCl}$ buffer ( $\mathrm{pH} 7.5$ ).

The reaction mixture $A$ was preincubated at $30^{\circ} \mathrm{C}$ for 30 min to convert a small amount of D-ribulose-5phosphate and D-xylulose-5-phosphate contaminating the D-ribose-5-phosphate solution to D-sedoheptulose7-phosphate and D-glyceraldehyde-3-phosphate. The reaction mixture $B$ was preincubated for $10 \mathrm{~min}$ and mixed with the reaction mixture A. After the oxidation rate of NADH became linear, an RPI sample $(10 \mu \mathrm{l})$ was added to the reaction mixture. After about $20 \mathrm{~min}$, the oxidation rate became linear and the change of absorbance at $340 \mathrm{~nm}$ for $10 \mathrm{~min}$ was calculated from the plot.

RPI activity was also determined by means of the carbazole reaction before partially purified RPE and TK were available. The reaction mixture contained $8 \mu$ moles of Tris-HCl buffer ( $\mathrm{pH} 7.5$ ), $1 \mu$ mole of $\mathrm{D}-$ ribose-5-phosphate and enzyme solution in a total volume of $0.1 \mathrm{ml}$. The reaction mixture was incubated at $30^{\circ} \mathrm{C}$ for $10 \mathrm{~min}$. The reaction mixture was subjected to determination of $\mathrm{D}$-ribulose-5-phosphate according to the method of Axelrod and Jang. ${ }^{3}$ b) Determination of RPE activity. The reaction mixtures A and B were as follows; A $(0.9 \mathrm{ml}): 20 \mu$ moles of D-ribose-5-phosphate, $20 \mu$ moles of $\mathrm{MgCl}_{2}$, $0.43 \mu$ mole of thiamine pyrophosphate, sufficient TK, and $40 \mu$ moles of Tris-HCl buffer ( $\mathrm{pH} 7.5) ; \mathrm{B}(1.09 \mathrm{ml})$ : $0.5 \mu$ mole of NADH, 0.66 unit of $\alpha$-glycerophosphate dehydrogenase containing sufficient triosephosphate isomerase, sufficient RPI and TK, and $60 \mu$ moles of Tris-HCl buffer (pH 7.5).

Procedure was the same as the case of RPI.

c) Determination of $T K$ activity. The reaction mixtures $\mathrm{A}$ and $\mathrm{B}$ were as follows; $\mathrm{A}(1.11 \mathrm{ml}): 20$ $\mu$ moles of D-ribose-5-phosphate, $0.5 \mu$ mole of NADH, enough amount of RPI and RPE, 0.66 unit of $\alpha$-glycerophosphate dehydrogenase containing enough amount of triosephosphate isomerase, and $60 \mu$ moles of Tris$\mathrm{HCl}$ buffer (pH 7.5), B $(0.89 \mathrm{ml}): 20 \mu$ moles of $\mathrm{MgCl}_{2}$, $0.43 \mu$ mole of thiamine pyrophosphate, $40 \mu$ moles of Tris- $\mathrm{HCl}$ buffer (pH 7.5), and $10 \mu \mathrm{l}$ of a TK sample. Each reaction mixture was preincubated at $30^{\circ} \mathrm{C}$ for $10 \mathrm{~min}$ and then the reaction mixtures were mixed.

D-Ribose-5-phosphate solution stored without alkali treatment was used as a substrate solution for the determination of TK activity before RPI and RPE preparations were obtained.

Determination of protein. Protein was determined by the method of Lowry et al. 26 ,

Chemicals. D-Ribose-5-phosphate was purchased from Seikagaku Kogyo Co. Ltd. and was used as a substrate after incubation with $1 \mathrm{~N} \mathrm{NaOH}$ for $10 \mathrm{~min}$ at room temperature and neutralization to exclude D-ribulose-5-phosphate and D-xylulose-5-phosphate. ${ }^{3}$ $a$-Glycerophosphate dehydrogenase containing triosephosphate isomerase was purchased from Calbiochem Inc. Egg white lysozyme and $\mathrm{NADH}$ were purchased from Sigma Chemical Company, Ltd.

\section{RESULTS AND DISCUSSION}

Preparation of partially purified RPI, RPE and $T K$

As described in Materials and Methods, it was necessary to obtain partially purified preparations of RPI, RPE and TK to determine the enzyme activities.

These enzymes have been purified from various materials previously. We selected Bacillus species No. 102 mutant G3-46-22-6, which is the parent strain of D-ribose-forming strains, as the enzyme source because it was readily available in our laboratories. However, its RPI and RPE were found to be so 
labile that spinach and baker's yeast were selected as enzyme sources for them, respectively (Table I).

Table I. Enzyme Activities in Cell Extracts

\begin{tabular}{lccc}
\hline Enzyme source & $\begin{array}{c}\text { D-Ribose- } \\
\text { 5-phosphate } \\
\text { isomerase }\end{array}$ & $\begin{array}{c}\text { D-Ribulose- } \\
\text {-5-phos- } \\
\text { phate 3- } \\
\text { epimerase }\end{array}$ & $\begin{array}{c}\text { Trans- } \\
\text { ketolase }\end{array}$ \\
\hline \multicolumn{4}{c}{$\mu$ moles/min/mg protein } \\
Spinach & 1.9 & 0.051 & 0.25 \\
(5 days) $^{a}$ ) & 2.3 & 0.046 & 0.22 \\
Baker's yeast $\left.^{\text {(7 days) }}\right)^{a}$ & 0.17 & 0.59 & 0.12 \\
G3-46-22-6 $^{\text {(5 days) }}{ }^{a}$ & 0.12 & 0.22 & 0.035 \\
\hline
\end{tabular}

a) Cell extracts were kept at $4^{\circ} \mathrm{C}$ in a refrigerator for the times shown.

a) Partial purification of spinach RPI by $D E A E$-cellulose and DEAE-Sephadex column chromatography. RPI and RPE of spinach were separated from TK by DEAE-cellulose column chromatography (Fig. 2A). RPI and RPE were not absorbed under the conditions used. Then, RPI was separated from RPE by DEAE-Sephadex A-50 column chromatography (Fig. 2B). The RPI fraction was used for the determination of RPE and TK activities. The RPI fraction was characterized by the production of a carbazole-positive product from D-ribose-5-phosphate (Table II).
The preparation contained no NADH oxidase and was very stable; no inactivation occurred in 7 months when it was stored at $-20^{\circ} \mathrm{C}$ in a freezer. RPI activity was very high in cell extract of spinach (Table I). Thus spinach is a very good source of RPI. After this investigation, a purified preparation of yeast RPI became obtainable commercially (Sigma Chemical Company). Detailed investigations on the properties of purified spinach RPI have also been reported by Rutner. ${ }^{24)}$

b) Partial purification of baker's yeast RPE by DEAE-cellulose column chromatography. RPE of backer's yeast was separated from RPI and TK by DEAE-cellulose column chromatography (Fig. 3). The RPE fraction was characterized by the fact that it neither formed D-glyceraldehyde-3-phosphate from stored Dribose-5-phosphate solution nor formed any carbazole-positive product from D-ribose-5phosphate (Table II). It also contained no NADH oxidase (Table II). It was the most unstable of the three enzyme preparations, but no inactivation occurred in a month when it was stored at $-20^{\circ} \mathrm{C}$ in a freezer. After this investigation, a purified preparation of yeast RPE became obtainable commercially (Sigma Chemical Company).

c) Partial purification of TK of Bacillus species No. 102 mutant G3-46-22-6 by DEAE-

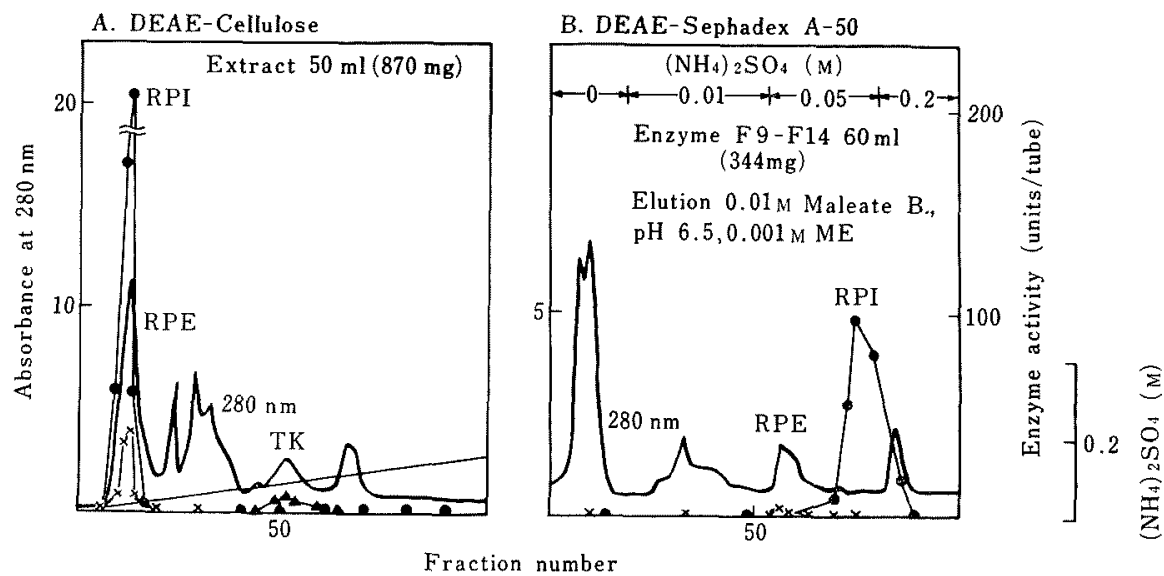

B. DEAE-Sephadex A-50

FIG. 2. DEAE-cellulose and DEAE-Sephadex Column Chromatography of Spinach Cell Extract. 
Table II. Properties of Enzyme Preparations

\begin{tabular}{|c|c|c|c|c|c|}
\hline $\begin{array}{c}\text { Enzyme } \\
\text { preparation }\end{array}$ & $\begin{array}{l}\text { Degree of } \\
\text { purification } \\
\text { over the } \\
\text { crude extract }\end{array}$ & Stability ${ }^{a}$ & $\begin{array}{l}\text { D-Ribose } \\
\text { 5-phosphate } \\
\text { isomerase } \\
\text { activity }\end{array}$ & Transketolase $^{c}$ & $\begin{array}{l}\text { NADH } \\
\text { oxidase } \\
\text { activity }\end{array}$ \\
\hline & fold & $\%$ & $\mathrm{OD}_{540}$ & $\mu \mathrm{mole} / \mathrm{min} / \mathrm{mg}$ & $\mu \mathrm{mole} / \mathrm{min} / \mathrm{mg}$ \\
\hline RPI of spinach & 54 & $\begin{array}{c}103 \\
\text { (7 months) }\end{array}$ & 0.187 & 0.00 & 0.00 \\
\hline RPE of yeast & 4.2 & $\begin{array}{r}94.3 \\
\text { (1 month) }\end{array}$ & 0.000 & 0.00 & 0.00 \\
\hline TK of G3-46-22-6 & 2.6 & $\begin{array}{c}91.3 \\
\text { (3 months) }\end{array}$ & 0.000 & 0.12 & 0.00 \\
\hline
\end{tabular}

a) Enzyme preparations were stored in a freezer.

b) Ten $\mu l$ of each enzyme preparation was used in the enzyme reaction.

v) The reaction mixture was the same as that described in the text for TK determination except that D-ribose-5-phosphate solution not treated with alkali was used as the substrate and RPI and RPE preparations were not added.

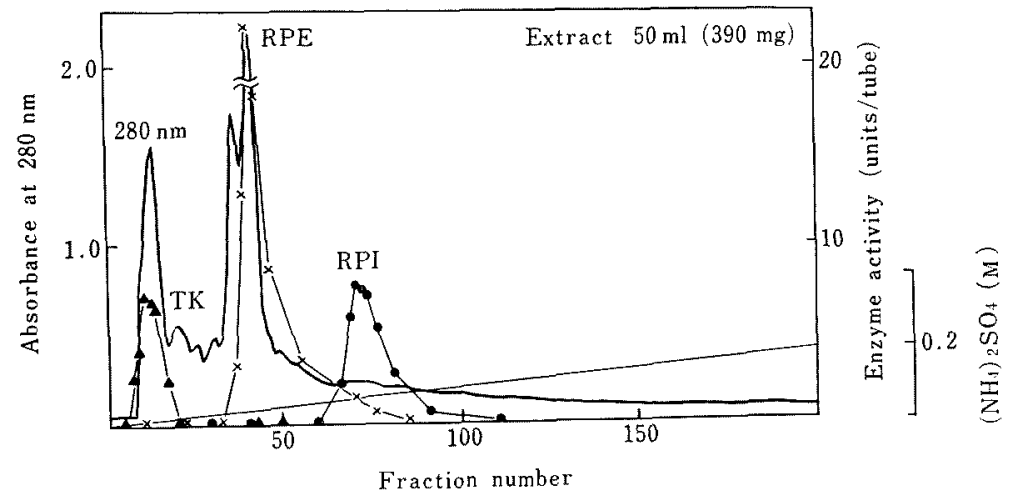

FIG. 3. DEAE-cellulose Column Chromatography of Baker's Yeast Cell Extract.

cellulose column chromatography. DEAEcellulose column chromatography of strain G3-46-22-6 cell extract was used to separate TK from RPI and RPE. The TK fraction was not completely free of RPE but could be used for the determination of RPI and RPE activities after storage for a month in a refrigerator because RPE from strain G3-46-22-6 was very unstable (Fig. 4). It was characterized by the fact that it formed D-glyceraldehyde3-phosphate from D-ribose-5-phosphate solution (Table II). It also contained no NADH oxidase (Table II). No inactivation occurred in three months when it was stored at $-20^{\circ} \mathrm{C}$ (Table II). TK of Candida utilis has been reported to be separable into three active fractions by DEAE-Sephadex column chromatography. ${ }^{17)}$
As described above, the three enzymes of spinach, baker's yeast and Bacillus sp. were separated by DEAE-cellulose and DEAESephadex column chromatography. The elution patterns on DEAE-cellulose column chromatography are considerably different. Each enzyme of each cell extract may be different in physicochemical properties.

Methods of determination of each enzyme activity

a) Concentrations of components in the reaction mixtures. The RPI, RPE and TK preparations obtained above were used for determination of the enzyme activities.

The optimum concentrations of the components were determined as described in MATERIALS AND METHODS. 


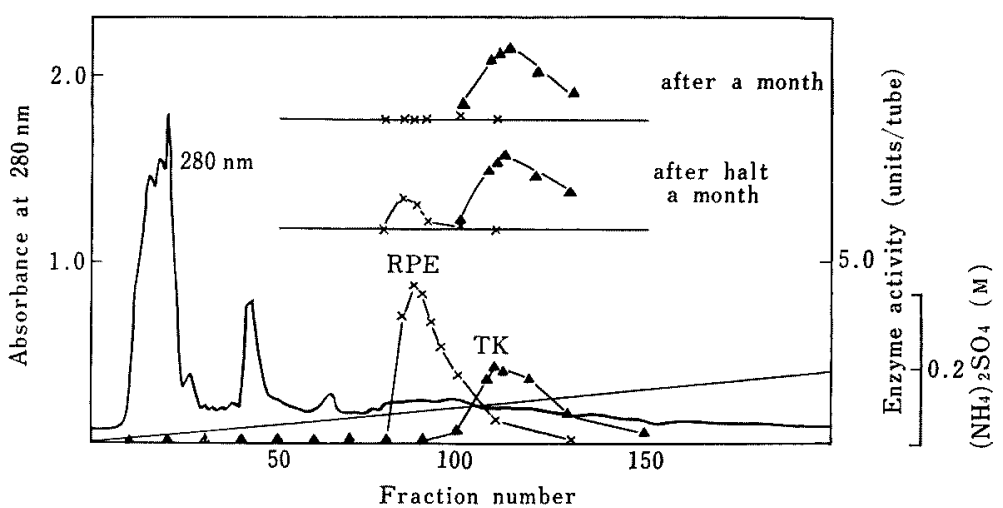

FIG. 4. DEAE-cellulose Column Chromatography of Bacillus Species Mutant G3-46-22-6 Cell Extract.

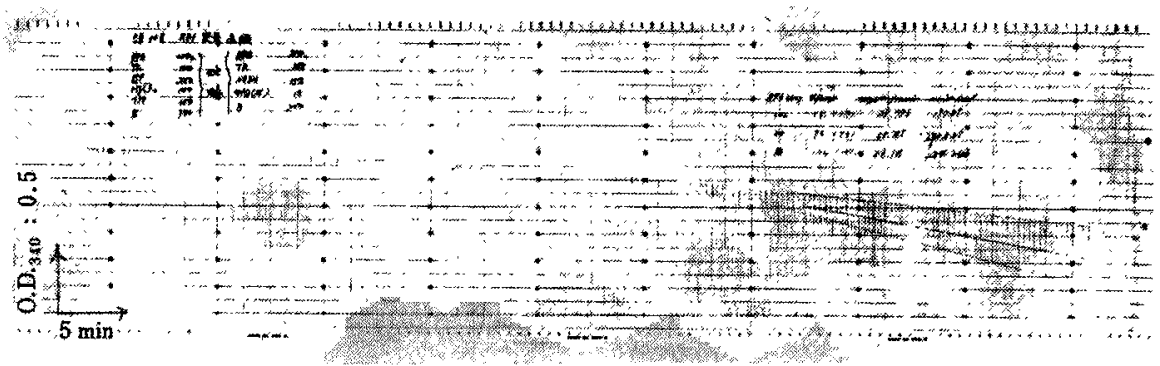

FIG. 5. Chart of RPI Determination.

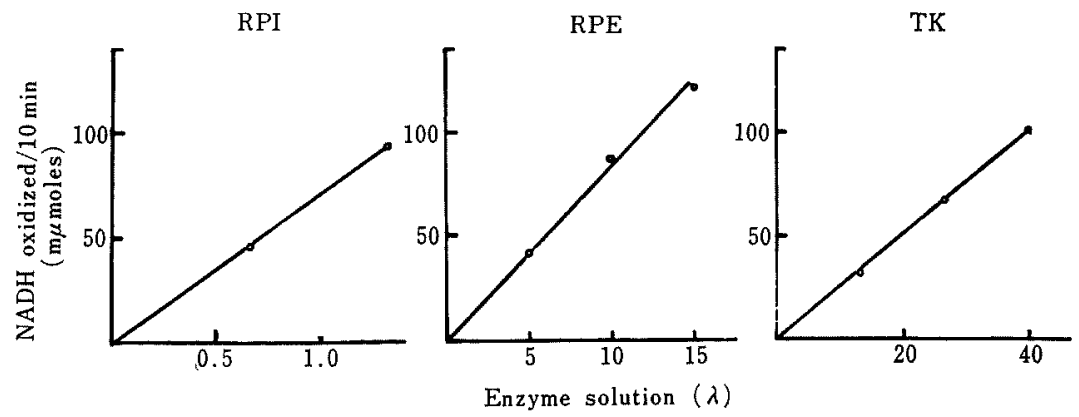

FIG. 6. The Effect of Protein Concentration on the Enzyme Activities.

b) Procedures. As described by Axelrod et al., ${ }^{3)}$ D-ribose-5-phosphate used in our laboratory also contained small amounts of D-ribulose-5-phosphate and D-xylulose-5phosphate. Although D-ribose-5-phosphate could be used practically after being treated with $1 \mathrm{~N} \mathrm{NaOH}$, the controls in the RPI and RPE determinations did not become linear instantly. In RPI and RPE determinations, the reaction mixtures $A$ were preincubated at $30^{\circ} \mathrm{C}$ for $30 \mathrm{~min}$ to remove D-ribulose-5phosphate and D-xylulose-5-phosphate. A chart for RPI determination is shown in Fig. 5.

c) Linearity. In each enzyme determination, the reaction rate was linear up to 0.01 unit of enzyme activity (Fig. 6).

d) Factors which interfere with the determination of $N A D H$ oxidation. The NADH oxidase activity of strain G3-46-22-6 varied 
with culture conditions; in the case of slightly anaerobic conditions such as a medium volume of $200 \mathrm{ml}$ in a one-liter flask, NADH oxidase activity was very weak, while the activity was high in the case of more aerobic conditions such as a medium volume of $100 \mathrm{ml}$ in a oneliter flask.

Other NADH oxidation activities must be present in the cell extracts because NADH oxidation in the absence of $\alpha$-glycerophosphate dehydrogenase was higher than the NADH oxidase activity described above. This may be due to D-ribulose-5-phosphate reductase or some such enzyme(s). Therefore, enzyme activities were subtracted from the apparent activities.

Determination methods thus established were used in an accompanying paper to determine the mutation points of D-ribose forming strains. $^{27)}$

Acknowledgement. We wish to thank Drs. R. Takeda and E. Ohmura for their continued interest and encouragement and Dr. M. Isono and Mr. I. Nakanishi for valuable discussions. Mr. T. Kumada and Miss S. Watanabe are also acknowledged for their skillful technical assistance.

\section{REFERENCES}

1) K. Sasajima, I. Nogami and M. Yoneda, Agr. Biol. Chem., 34, 381 (1970).

2) K. Sasajima and M. Yoneda, ibid., 35, 509 (1971).

3) B. Axelrod and R. Jang, J. Biol. Chem., 209, 847 (1954).

4) G. de la Haba, I. G. Leder and E. Racker, ibid., 214, 409 (1955).

5) J. Cooper, P. A. Srere, M. Tabachnick and E. Racker, Arch. Biochem. Biophys., 74, 306 (1958).

6) M. Tabachnick, P. A. Srere, J. Cooper and E. Racker, ibid., 74, 315 (1958).

7) J. Hurwitz and B. L. Horecker, J. Biol. Chem.,
223, 993 (1956).

8) B. L. Horecker, P. Z. Smyrniotis and J. Hurwitz, J. Biol. Chem., 223, 1009 (1956).

9) E. Racker, "The Enzymes," Vol. 5, ed. by P. D. Boyer, H. Lardy and K. Myrbäck, Academic Press, Inc., New York, 1961, pp. 397, 407.

10) F. Novello and P. McLean, Biochem. J., 107, 775 (1968).

11) E. L. Tan and T. Wood, Comp. Biochem., 31, 635 (1969).

12) B. L. Horecker, "Biochemist's Handbook," ed. by C. Long, E. J. King and W. M. Sperry, E \& F. N. Spon, Ltd., 1961, pp. 432, 509.

13) G. de. la Haba and E. Racker, "Methods in Enzymology," Vol. 1, ed. by S. P. Colowick and N. P. Kaplan, Academic Press Inc., New York, N. Y., 1957, p. 375.

14) T. Horitsu and M. Tomoeda, Agr. Biol. Chem., 30, 956 (1966).

15) P. Srere, J. R. Cooper, M. Tabachnick and E. Racker, Arch. Biochem. Biophys., 74, 295 (1958).

16) W. A. Wood and M. W. McDonough, Fed. Proc., 18, 354 (1959).

17) M. E. Kiely, E. L. Tan and T. Wood, Can. J. Biochem., 47, 455 (1969).

18) W. Yaphe, D. D. Christensen, J. E. Biaglow, M. A. Jackson and H. Z. Sable, ibid., 44, 91 (1966).

19) J. David and H. Wiesmeyer, Biochim. Biophys. Acta, 208, 56 (1970).

20) K. Matsushima and F. J. Simpson, Can. J. Microbiol., 12, 313 (1966).

21) G. Ashwell and J. Hickman, J. Biol. Chem., 226, 65 (1957).

22) B. L. Horecker and P. Z. Smyrniotis, "Methods in Enzymology," Vol. 1, ed. by S. P. Colowick and N.P. Kaplan, Academic Press Inc., New York, N. Y., 1957, p. 371.

23) M. Urivetzky and K. K. Tsuboi, Arch. Biochem. Biophys., 103, 1 (1963).

24) A. C. Rutner, Biochem., 9, 178 (1970).

25) P. A. Srere, J. R. Cooper, K. Klybas and E. Racker, Arch. Biochem. Biophys., 48, 238 (1954).

26) O. H. Lowry, J. J. Rosebrough, A. L. Farr and R. J. Randall, J. Biol. Chem., 193, 265 (1951).

27) K. Sasajima and M. Yoneda, Agr. Biol. Chem., 38, 1305 (1974). 